\title{
IMPROVEMENT OF ORGANIZATIONAL CULTURE, SERVICE QUALITY AND USE OF INFORMATION TECHNOLOGY AND ITS IMPLICATIONS ON ACADEMIC PERFORMANCE IN STUDENTS OF ACCOUNTING STUDY PROGRAMS
}

\author{
Hiras Pasaribu \\ Staf Pengajar Jurusan Akuntansi \\ Universitas Pembangunan Nasional "Veteran" Yogyakarta \\ e-mail : hiras.pasaribu@upnyk.ac.id \\ Indah Kartika Sandhi \\ Staf Pengajar Jurusan Akuntansi \\ Universitas Pembangunan Nasional "Veteran" Yogyakarta \\ e-mail : indahkartika@upnyk.ac.id \\ Gita Astyka Rahmanda \\ Staf Pengajar Jurusan Akuntansi \\ Universitas Pembangunan Nasional "Veteran" Yogyakarta \\ e-mail : gitaastika.ga@gmail.com \\ Siti Rokhimah \\ Staf Pengajar Jurusan Akuntansi \\ Universitas Pembangunan Nasional "Veteran" Yogyakarta \\ e-mail : sitirokhimah@upnyk.ac.id
}

\begin{abstract}
This study aims to determine the effect of organizational culture which has a proxy for achievement culture, academic service quality and the use of information technology on student academic performance. The data source is derived from a questionnaire given to students of the Yogyakarta Veterans National Development Study Accounting Program. The questionnaire uses a Likert scale with a population of 1020 students. The research method uses a survey to students. The sample is done using simple random sampling. The minimum sample was taken $10 \%$ of the population, which is 102 increased to 200 students who are taking semester five to semester eight. Because students who are respondents, so far have experienced receiving academic services. The data analysis tool uses multiple regression. Primary data collected are first tested for validity, reliability, and normality and then analyzed by multiple regression. The results of this regression to determine the effect of independent variables with the dependent variable. The expected output can be an additional reference to improve the culture of achievement, service quality and implications for student academic performance. The results found that the use of information technology has a positive effect on student academic performance, while the organizational culture which is proxy from the culture of achievement, and the quality of academic services do not influence student academic performance.
\end{abstract}




\begin{abstract}
ABSTRAK
Penelitian ini bertujuan untuk mengetahui pengaruh budaya organisasi yang diproksikan dengan budaya berprestasi, kualitas pelayanan akademik dan penggunaan teknologi informasi terhadap prestasi akademik mahasiswa. Sumber data berasal dari angket yang diberikan kepada mahasiswa Program Studi Akuntansi Pembangunan Nasional Veteran Yogyakarta. Angket menggunakan skala likert dengan populasi 1020 siswa. Metode penelitian menggunakan survei kepada siswa. Pengambilan sampel dilakukan dengan menggunakan simple random sampling. Sampel minimal diambil 10\% dari populasi yaitu 102 meningkat menjadi 200 mahasiswa yang menempuh semester lima hingga semester delapan. Pasalnya, mahasiswa yang menjadi responden, selama ini sudah berpengalaman menerima layanan akademik. Alat analisis data menggunakan regresi berganda. Data primer yang dikumpulkan terlebih dahulu diuji validitas, reliabilitas, dan normalitasnya kemudian dianalisis dengan regresi berganda. Hasil regresi ini untuk mengetahui pengaruh variabel independen dengan variabel dependen. Output yang diharapkan dapat menjadi acuan tambahan untuk meningkatkan budaya berprestasi, kualitas pelayanan dan implikasinya terhadap prestasi akademik mahasiswa. Hasil penelitian menemukan bahwa penggunaan teknologi informasi berpengaruh positif terhadap kinerja akademik mahasiswa, sedangkan budaya organisasi yang diproksikan dari budaya berprestasi, dan kualitas layanan akademik tidak berpengaruh terhadap kinerja akademik mahasiswa.
\end{abstract}

Kata Kunci : Budaya kinerja, kualitas layanan, teknologi informasi, prestasi akademik mahasiswa.

\title{
BACKGROUND
}

The quality of human resources is one of the important things in supporting the implementation of good performance activities. Higher education as one of the institutions to increase the competitiveness of human resources continues to improve to meet market demand for the required labor qualifications. Improving the quality of human resources through education in high school certainly requires appropriate academic planning to achieve goals and achieve satisfactory results. Good academic planning will be achieved if it goes hand in hand with the academic performance services offered by the College.

Creating students who can think intelligently and critically becomes one of the goals in accounting education (Schleifer and Dull, 2009). The ability to learn and maintain professional skills, knowledge, and orientation are important things that need to be prepared so that students can succeed in the world of work.

Cluster ranking by the Ministry of Research, Technology and Higher Education as one of the activities to support the quality of higher education output. Based on the Ministry of Research and Technology Press Release Number: 147 / SP / HM / BKKP / VIII / 2019, Higher Education Ranking 2019 focuses on Output- Outcome Base -based indicators or assessments , namely by looking at Input Performance with a weight of $40 \%$ which includes Input performance (15\%) and Process (25\%), and Output Performance with a weight of $60 \%$ which includes Output Performance (25\%), and Outcome (35\%). The addition of these new indicators is an effort so that universities can actively respond to the times, especially the 4.0 industrial revolution.

Output assessment can be done by looking at academic performance. Various dimensions to measure academic performance include the dimensions of service quality, including aspects of tangibles (educational infrastructure), reliability (reliability of lecturers and 
academic staff), responsiveness (responsiveness), assurance (treatment of students) and empathy (understanding of student interests). The dimensions of organizational culture include aspects of curriculum, learning and academic atmosphere, students and graduates, students and graduates, human resources, academic facilities and infrastructure, research, community service and cooperation, management systems. Dimensions of information technology, including aspects of the standard use of information systems in the academic field, curriculum standards, and learning.

Many numbers of points regarding the importance of student academic performance were expressed by several researchers. Guney (2009) states that research on student academic performance is an important topic in the world of education. Finding factors that influence student academic performance is very important for universities, lecturers and in some cases for students themselves. These factors will greatly affect university academic policy, improvement of the curriculum, assessment of lecturers' performance and modification of the way lecturers teach. Kaighobadi and Allen (2008) stated that research on the academic performance of students received great attention from stakeholders in the world of education. The goal is to find out the factors that need to be improved in improving student academic performance to improve the quality of learning.

Organizational culture can be reflected in the system which includes the level of opportunity for innovation and creation for employees, the formation of work teams, transparent leadership and not too bureaucratic (Pratama, 2012: 18). It means that the culture that develops in the faculty provides direction and behavior patterns for the academicians in it, especially for academic service employees. Soejono's research (2005) states that organizational culture has a significant and positive effect on organizational performance and job satisfaction. Organizational culture is related to believed values, rules and codes of conduct that are characteristic of a group or an academic service employee in handling an issue. The values and regulations contained in the organizational culture of the faculty must be understood and applied by lecturers in carrying out their activities on campus. The better the level of implementation of organizational cultural values in an entity the better the performance of the organization.

Academic services provided by tertiary institutions are one measure of the success of higher education institutions in managing their educational institutions in the context of providing educational service products. This has resulted in educational institutions needing to continuously improve the quality of services and academics (Qomariah, 2012). Academic Service Quality is important to create academic community satisfaction as a form of good academic performance at the tertiary institution concerned.

Demands for the development of information 4.0 in the world of education, the existence of information technology in academia can improve service performance for users. Research on academic services and the use of information technology and academic governance as an organizational culture to improve academic performance have not been much studied by previous researchers. This research will develop several previous studies by adding the level of existence of the use of information system technology in revealing an increase in academic performance in the Accounting Study Program of the Faculty of Economics and Business UPN "Veterans" Yogyakarta.

FORMULATION OF THE PROBLEM

Based on the description above, researchers can formulate the problem as follows:

1. Does the organizational culture have a positive effect on student academic performance?

2. Does service quality ( tangibles, reliability, responsiveness, assurance, empathy) have a positive effect on student academic performance? 
3. Does the use of information technology have a positive effect on student academic performance?

\section{LITERATURE REVIEW AND DEVELOPMENT OF HYPOTHESES}

1) Organizational Performance (Academic)

The quality of education implementation can be seen as one of them in terms of organizational performance (academic). Rummler and Brachein (Sudarmanto, 2009 ) say that achieving results at the level or unit of organizational analysis is related to organizational goals, organizational design, and organizational management. Information about organizational performance becomes an important matter considering the goals of the institution/organization have been previously determined (Bambang, 2018). This becomes important for the Accounting Study Program of the Faculty of Economics UPN "Veterans" Yogyakarta to analyze organizational (academic) performance.

2) Organizational Culture

The growth and development of an organization are very closely related to the organizational culture created therein. Organizational culture is often interpreted as being very crucial in improving the performance of an organization in terms of realizing its goals. Organizational culture (Irianto, 2019) is defined as a value that has certain characteristics because each organization has a fundamental difference between one organization and another. Furthermore, Mas'ud (2004) explains that organizational culture becomes the identity or main character of an organization that is nurtured and maintained. Each organization has cultural differences from one another. This is due to differences in human character that is in it, causing differences in organizational behavior.

Organizational culture is very closely related to the performance of an organization. Arifin (2010) explains that Performance is used by management to conduct periodic evaluations of an organization's operational effectiveness, employee effectiveness based on its main tasks and functions (TUPOKSI) based on predetermined standards. Several studies have shown a relationship between one another's organizational culture and the performance of an organization.

The results of the research by Astuti and Ike (2010), organizational culture has a significant and positive effect on organizational performance. Likewise, the results of researcher Soejono (2005) state that organizational culture has a significant and positive effect on organizational performance and job satisfaction. Djokosantoso, (2003) who stated that the better the quality of the factors contained in organizational culture, the better the performance of the organization.

Likewise, the results of research by Chatman and Bersade (1997) and UdanBintoro (2002) state that a strong organizational culture can improve organizational performance. Jaya, AgamWie (2013) concluded in his research, there was a positive influence between Organizational Culture on Employee Performance in the HR Division of PT INTI Persero.

3) Quality of Service

One of the things that can increase customer satisfaction is a good quality of service to customers. Similarly, educational institutions such as universities. Academic Service Quality is important to create academic community satisfaction as a form of good academic performance at the tertiary institution concerned. Ruslan (2012) suggested that the Quality of Service ( Service of Excellence ) is the rate to expected and know on the level of excellence to meet customer desires. Quality of service at the tertiary level includes information services, facilities, and infrastructure services, academic services and academic guidance services. According to Sugiyanti in Mahmud (2012), states that tertiary institutions are services there are attributes that should receive attention in improving service quality, (1) 
timeliness of service, (2) accuracy of service, (3) politeness and friendliness in providing services, ( 4) responsibilities, (5) completeness, regarding the scope of services and the availability of supporting facilities and other complementary services, (6) ease of getting services, (7) variations in service models, such as new patterns and features of services and others, (8) personal services, related to flexibility, handling special requests or so on, (9) comfort in obtaining services, (10) other supporting attributes, such as the environment, cleanliness, waiting room, music facilities, air conditioning and others.

This study uses 5 (five) factors that determine the quality of services developed from Kotler's statement, (2000) include: (1) tangible (direct evidence) including physical facilities, equipment, employees, and communication facilities; (2) reliability, which is the ability to provide the promised service immediately, accurately and satisfactorily; (3) responsiveness , which is the desire of staff to help customers and provide services responsively; 4) assurance , including knowledge, competence, courtesy, and trustworthiness of staff, free from danger, risk or doubt; (5) empathy (empathy), including ease in establishing relationships, good communication, personal attention, and understanding of the individual needs of customers.

4) Availability of Use of Information Technology

No doubt information is very important in various aspects of life, especially for decisionmaking needs. According to Rainer, Turban, Potter (2001), information is data/fact that has been processed in such a way, so that it changes its form into information. Furthermore, William (2007) argues that information technology is a technology that combines computing (computers) with high-speed communication lines that carry data, voice, and video. Information technology is the main pillar to help the performance of the organization so that work can be done more easily and informative to the user.

The speed of service is determined by the availability of appropriate information. The availability of information can be determined using efficient information technology but can provide the information needed by information users. Information that is useful for users is information that has value. Information will be useful if the information can support decision making and can be understood by users (Suwardjono, 2008). Therefore, information providers must pay attention to the relevance of the information presented. Information technology can be said to be the science needed to manage information so that information can be searched easily and accurately ( Kusuma, Arief AP, 2014). The contents of this knowledge can be in the form of techniques and procedures for storing information efficiently and effectively. Information can be said as data that has been processed. This information can be in the form of weather forecasts, letters, news, research and development publications or educational or training programs, such as welding techniques, cooking methods, music lessons or other lessons. This information can be stored in the form of text, sound, dead pictures or live images. So that the final information can be in the form of knowledge and knowledge itself (Kusuma, Arief AP, 2014). This means the use of information technology is measured by the ease of finding accurate data and is needed by the user, storing information with procedures and techniques that are efficient and effective.

The size of the volume of information can be adjusted with the right technique or procedure. If the volume is small, of course, no complicated techniques or procedures are needed to store it. However, if the information is in a large volume, certain techniques and procedures are needed to store it so that it is easy to find the information stored. Computers can store information in large volumes. Because today, computers have been able to store information in various forms, for example in the form of sound, dead images, live images, even a combination of live images and sound in the form of film. 
Every institution, there is information that needs to be communicated from one section to another. Simply communicating information is to move the information to another place. However, if there is a distance between the sender and receiver of information, the delivery process will be problematic. In situations where the number of parties requiring information is large and the information needed varies, the process of delivering that information becomes more complicated. The presence of a combination of computer technology, information technology, and communication technology or telecommunications greatly facilitates the delivery of information in a form that has been identified.

\section{RESEARCH METHODOLOGY}

This research was conducted at the Faculty of Economics and Business (FEB) UPN "Veterans" Yogyakarta. The independent variables in this study are Organizational Culture $\left(\mathrm{X}_{1}\right)$, Service Quality $\left(\mathrm{X}_{2}\right)$, and Use of Information Technology $\left(\mathrm{X}_{3}\right)$. The dependent variable in this study is Student Academic Performance (Y). This study uses a Likert scale (15) with the population in this study is a student of Accounting Study Program UPN "Veteran" Yogyakarta as many as 1200 students. The sample used was 200 students.

The following multiple regression models in this study: Multiple Regression Model

$$
\begin{aligned}
& \mathrm{Y}=\mathrm{a}+\mathrm{b} \mathrm{X}_{1}+\mathrm{bX}_{2}+\mathrm{b} \mathrm{X}_{3}+\mathrm{e} \\
& \mathrm{Y}=\text { Student Academic Performance } \\
& \mathrm{a}=\text { constant } \\
& \mathrm{X}_{1}=\text { Organizational Culture } \\
& \mathrm{X}_{2}=\text { Service Quality } \\
& \mathrm{X}_{3}=\text { Use of Information Technology }
\end{aligned}
$$

$\mathrm{e}=$ error .

\section{RESULTS}

This research is institutional research at the Accounting Department of FEB UPN Veteran Yogyakarta. This study consists of three independent variables and one dependent variable. The independent variables are Organizational Culture (X1 ), Service Quality (X2 ), Use of Information Technology (X3). The dependent variable in this study is Academic Performance (Y).

Descriptive statistical analysis results on the dependent variable (Student Academic Performance) shows that the minimum value is 9 , the maximum value is 30 . The average respondent's answer is 18.32 with a standard deviation of 3.613. Descriptive statistical analysis results on the independent variable (Organizational Culture) shows that the minimum value is 7 , the maximum value is 20 . The average respondent's answer is 15.68 with a standard deviation of 3,881 .

In testing the first hypothesis to test the effect between Organizational Culture (X1) and Student Academic Performance (Y). The results of data processing show the value of the $\mathrm{H} 1$ significance level of 0.750 (more than 0.05). This shows that there is no influence of Organizational Culture on Academic Performance. This result proves that whether the organizational culture in an agency is good or bad cannot describe the students' good or bad academic performance.

In testing the second hypothesis to test the effect between Academic Service Quality (X2) and Student Academic Performance (Y). The results of data processing show the value of the $\mathrm{H} 2$ significance level of 0.178 (more than 0.05). This means that Service Quality does not 
affect Student Academic Performance. The data shows that Service Quality does not have a positive contribution to Student Academic Performance. This shows that the quality of services provided by an organization does not necessarily help students to get the best results in their academics. The era shift requires students to be more active and proactive in achieving optimal academic results.

In the second hypothesis testing to test the effect between the Use of Information Technology (X3 ) and Student Academic Performance (Y). The results of data processing indicate that the value of the significance level of $\mathrm{H} 3$ is 0.008 (less than 0.05). These results indicate that the higher the level of Use of Information Technology, the higher the Academic Student Performance. If the Use of Technology increases by $1 \%$, the variable Organizational Culture and Service Quality remain, then the value of Student Academic Performance will increase by 0.008 . This shows that the use of Information Technology has a positive contribution to Student Academic Performance.

\section{CONCLUSIONS AND SUGGESTION}

The results of this study show that :

1) Organizational Culture and Service Quality do not influence the Academic Performance of accounting students at the FEB UPN Veterans Yogyakarta.

2) The use of Information Technology has a positive effect on the Academic Performance of Students in Accounting FEB UPN Veterans Yogyakarta students.

The following are suggestions for this research:

1) To improve the academic performance of students, efforts need to be made to improve the culture of the organization through training activities for related academics and improving information technology and service quality in the academic section.

2) Conduct comparative studies to other universities that have high student academic performance, in the context of observation and follow up to create good student academic performance.

\section{REFERENCE}

Bambang K. 2008. Audit Mutu Internal PerguruanTinggi. Tersedia: www.kinerja perguruan tinggi. (diunduh, 8-2-2010)

Bintoro, Udan. 2002. Pengaruh Praktek Manajemen Sumber Daya Manusia terhadap Budaya Organisasi dan Kinerja Perusahaan. DisertasiUniversitasAirlangga, Surabaya.

Chatman, Jennifer and Bersade, 1997. Employee Satisfaction, Factor Associated With Company Performance, Journal Of Applied Psychology, February, 29 - 42.

Djokosantoso, Moeljono. 2003. BudayaKorporat dan KeunggulanKorporasi, Elex Media Komputindo, Jakarta

Guney, Yilmaz. 2009. "Exogenous and Endogenous Factors Influencing Students' Performance in Undergraduate Accounting Modules", Accounting Education: an international journal.Vol. 18, No. 1, pp. 51-73.

Jaya, AgamWie. 2013. Pengaruh Budaya Organisasi Terhadap Kinerja Karyawan Pada Divisi $\mathrm{Sdm} \quad \mathrm{Pt}$ Inti Persero; http://Repository.Widyatama.Ac.Id/Xmlui/Handle/123456789/4417. Widyatama Repository, AksesTanggal 15 Maret 2016. 
Kaighobadi, Mehdi dan Marcus T. Allen. 2008. "Investigating Academic Success Factors for Undergraduate Business Students" Decision Sciences Journal of Innovative Education. Volume 6 Number 2. pp.427-436.

Kotler, P. 2000. Marketing management 9th edition. New Jersey. Prentice Hall International. Inc.

Kusuma, arief AP. 2014.http://www.esaunggul.ac.id/article/pemanfaatan-teknologiinformasi-dalam-proses-pengajaran-di-indonesia-2/

Mahmud, Marzuki. 2012. Manajemen Mutu Perguruan Tinggi, Jakarta :Rajawali Pers.

Mas’ud. 2001.Survey Diagnosis Organizational. Undip, Semarang.

Pratama, Yoga. 2012. Pengaruh Budaya Organisasi Terhadap Kinerja Pegawai di Kantor Kecamatan Nanggung Kabupaten Bogor, Depok: Prodi Administrasi Negara, Fisip, UI.(Skripsi).

Qomariah, N. (2012). Pengaruh Kualitas Layanan dan Citra Institusiterhadap Kepuasan dan Loyalitas Pelanggan (StudipadaUniversitas Muhammadiyah di JawaTimur). Jurnal Aplikasi Manajemen.10 (1), 177-187.

Rainer, Turban, Potter, 2001. Introduction to Information Technology. John Wiley \& Sons, Inc.

Ruslan, Rosady. 2012. Manajemen Public Relation dan Media Komuniasi. Jakarta: PT Raja GrafindoPersada.

Schleifer, Lydia L. F. dan Richard B. Dull. 2009. "Metacognition and Performance in The Accounting Classroom”, Issues In Accounting Education. Vol. 24, No. 3. pp. 339-367.

Sekaran, Uma. 2000. Research Methods for business: A Skill Building Approach. Singapore: John Wiley \& Sons, Inc.

Soedjono. 2005. Pengaruh Budaya Organisasi Terhadap Kinerja Organisasi .Jurnal Manajemen \& Kewirausahaan, Vol. 7 (1), Maret 2005: 22- 47

Suwardjono. 2008. Teori Akuntansi: Perekayasaan Pelaporan Keuangan. Edisi Ketiga. Yogyakarta: BPFE-Yogyakarta

William \& Sawyer. 2007. Using Information Technologi. Yogyakarta: Penerbit Andi. 